\title{
MULTILAYERED APPROACH TO MODEL PREDICTIVE INDUSTRIAL PROCESS CONTROL
}

\author{
L.S. Kazarinov, kazarinovls@susu.ru, \\ D.A. Shnayder, polytech@mail.ru, \\ T.A. Barbasova, tatyana_barbasova@mail.ru \\ South Ural State University, Chelyabinsk, Russian Federation
}

\begin{abstract}
The method of the industrial processes efficiency increasing based on the multilayered approach to the control task solution is proposed in the article. According to this approach the existing technology regulations of estimation process conducting in terms of the true accuracy of operating parameters holding is used as the regulatory constraint defining their acceptable region. Within the field specified the process of the controlled operating parameters values optimization according to the current data about operation is implemented. The optimization process is based on multidimensional simplex method usage and orthogonal planning of problem solving in combination with the method of effective domain elliptic approximation. The example of using the proposed method for the blastfurnace process efficiency increasing is given.
\end{abstract}

Keywords: blast-furnace process, multilayered approach, elliptic approximation method, modelpredictive control.

\section{Introduction}

The majority of papers on industrial processes control automation nowadays are concerned with solving of the basic task of automation which consists of the following subtasks: 1) automatic control system construction on the lower level, 2) construction of the automatic processes monitoring system on the upper level. It results from the fact that the problems of industrial processes automated control in general are much more difficult and more important in comparison with problems of local automation and monitoring. The technique of industrial processes basic automation is well developed in terms of both hardware and software nowadays. However, the greatest economic benefit can be achieved in case of the industrial processes control automation by the criteria of technical and economic efficiency [1-3].

The main difficulties impeding achievement of high rates of the industrial processes technical and economic efficiency are:

1) partial processes' observability and controllability;

2) necessity to regulate the processes in extreme boundary conditions;

3 ) incomplete information on the processes current states owing to their complexity.

To overcome the difficulties specified the advanced methodology of the model predictive control is developing now. The specific feature of this method is that to provide processes' observability and controllability the applicable mathematical models are used. These models are constantly updated being online with the object controlled on the bases of the procedures of their continuous parameters identification by the current actual data. Thus on each stage of control, the problem of the control actions optimization according to technical and economic indicators is solved. Calculated optimal control actions are fed to the object inputs, monitoring of the results obtained and correction of the model are carried out according to the actual data obtained.

Taking into account all mentioned above, it is quite urgent to develop the model predictive automated control systems of the industrial processes [4-15].

Vital issue of the model predictive control application is the combination of the existing technologies of processes control determined by process regulations and new methods of data mining.

It is the problem of combination of the existing processes control technology which is based on the fundamental scientific and practical knowledge providing certain reliability and the control task solution validity with the information available in the current data of process control. The process regulations determine the acceptable decisions concerning the process control whereas the current information about it allows making the step forward in the process efficiency within the process regulations. Solution 


\section{Автоматизированные системы управления}

of this task seems to be possible by using the multilayered approach to the control decisions making. We can mention the papers devoted to the fuzzy neural networks using for arc steel-making furnaces [16] as an example of such approach application.

In this paper the method of industrial processes efficiency increasing based on the multilayered approach to the control task solution is offered. Thus the existing process regulation is estimated in terms of the real accuracy of the operational parameters holding and used as the regulatory restriction determining the acceptable region. Within the specified region the optimization process of the operated standard parameters values according to the current data of operation is implemented. Optimization process is based on the multidimensional simplex method and orthogonal planning of decision making in combination with the elliptic approximation of effective domain method.

\section{The structure of the model predictive control system}

Generalized structure of the model predictive control system is given in Fig. 1.

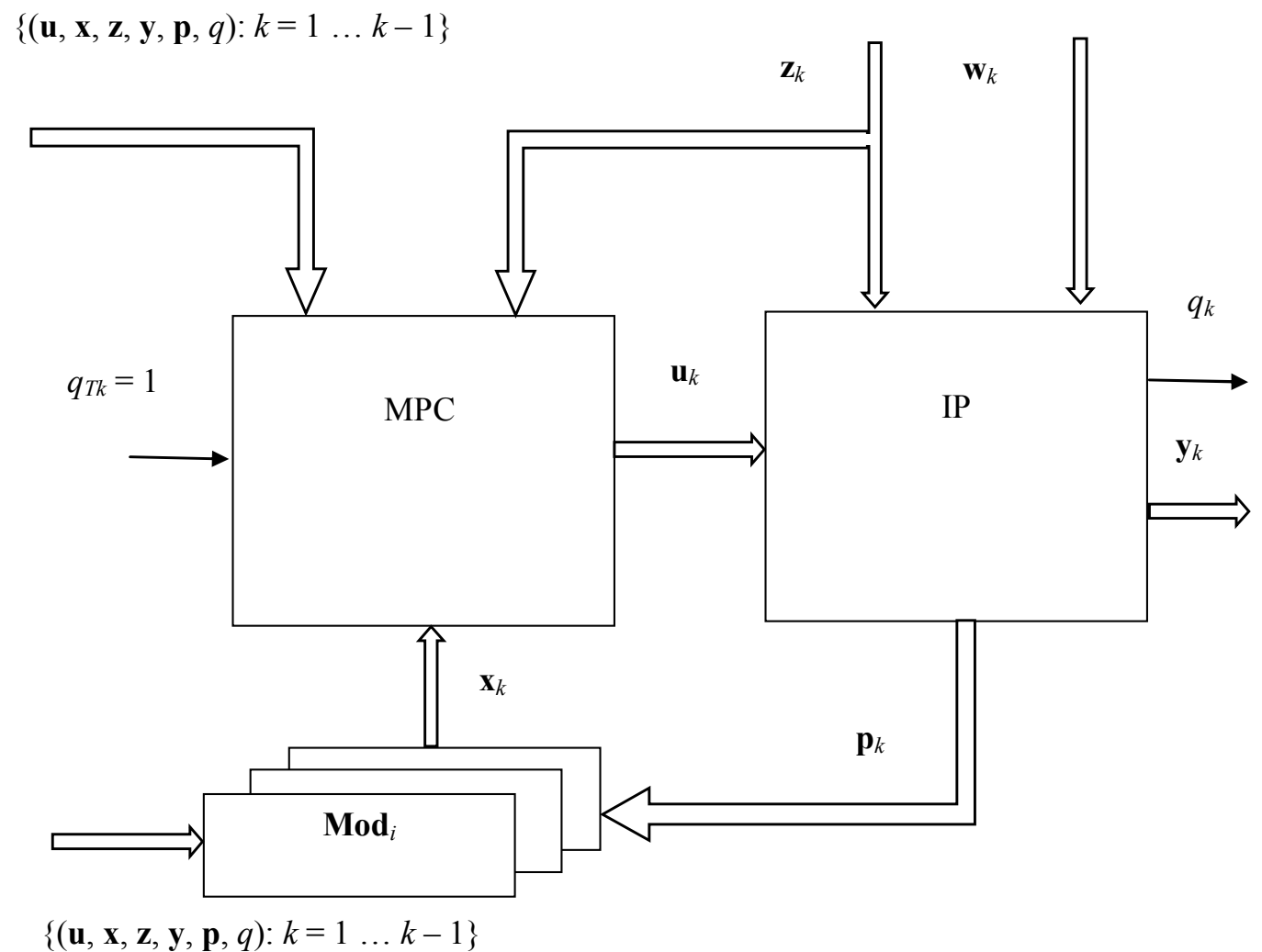

Fig. 1

In Fig. $1 \mathbf{u}_{k}-$ the controlled parameters of industrial process (IP);

$\mathbf{z}_{k}$ - measured uncontrollable IP factors;

$\mathbf{w}_{k}-$ not measured perturbing IP factors;

$\mathbf{q}_{k}$ - IP efficiency index;

$q_{k i}= \begin{cases}1, & \text { if the industrial process meets the efficiency index specified; } \\ 0, & \text { otherwise. }\end{cases}$

$\mathbf{y}_{k}$ - measured output parameters of IP;

$\mathbf{x}_{k}$ - state vector of blast-furnace process on the basis of which the satisfactory forecast of its characteristics is provided;

$\mathbf{p}_{k}$ - the measured IP parameters used for its state vector estimation;

$\{(\mathbf{u}, \mathbf{x}, \mathbf{z}, \mathbf{y}, \mathbf{p}, q): k=1 \ldots k-1\}$ - previous statistics of the IP parameters.

$\operatorname{Mod}_{i}$ - the IP model representations corresponding to $i$ standard technological instructions which provide an assessment of its state vector values;

MPC -model predictive control calculation program;

$k$-index of the current industrial process. 


\section{Optimal control formation concept}

According to the modern theory of optimal linear control the command vector is determined by the ratio:

$\mathbf{u}=\mathbf{K}_{o p t} \cdot \mathbf{x}$,

where $\mathbf{K}_{\text {opt }}$ - matrix of optimal coefficients of state and control relations; $\mathbf{u}$ - command vector; $\mathbf{x}$ - controlled process state vector.

In case of blast-furnace process the state vector is a set of all information available on blast-furnace process before and in the course of blast-furnace smelting which is measured or calculated by known technological formulas and on which basis it is possible to forecast the finite values of blast-furnace smelting parameters well.

If there are no perturbing factors, the dependence (1) has the determined form (Fig. 2).

As industrial process is characterized by the presence of not measured perturbing factors, in this paper dependence (1) is presented in the form of the generalized elliptic area (Fig. 3). It is possible to call this area paraelliptic one, as an acronym from parallelepiped + ellipsoid.

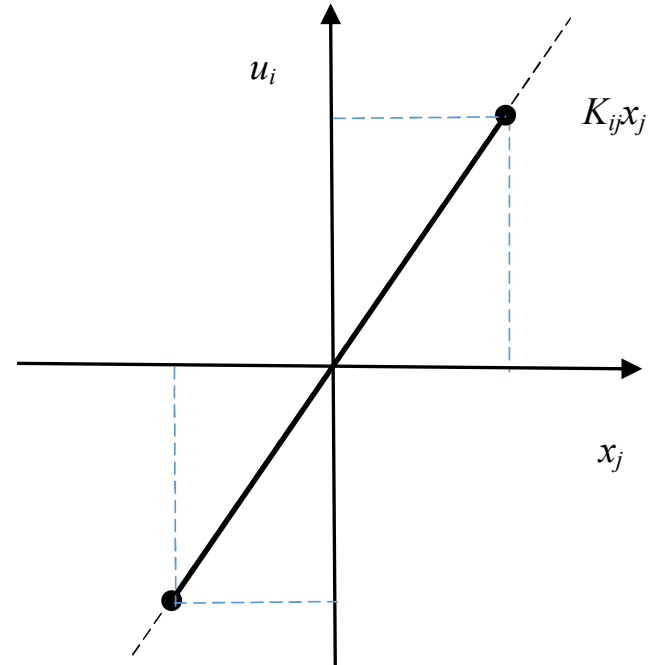

Fig. 2

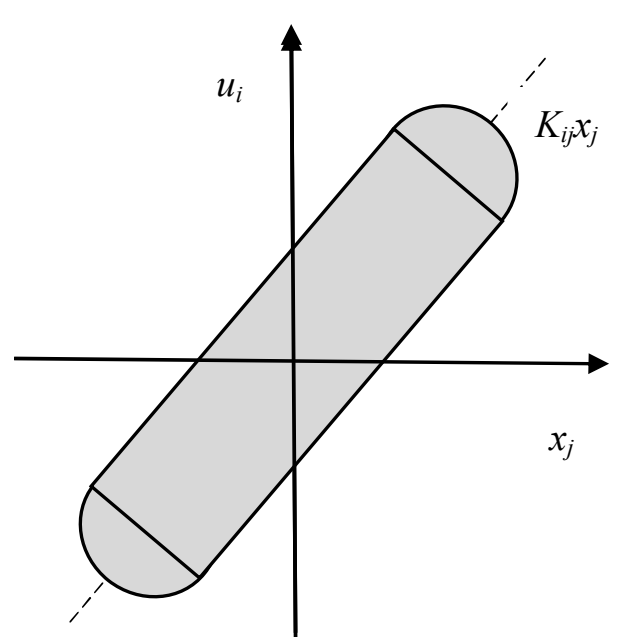

Fig. 3

On the basis of these paraelliptic areas in operating parameters values space subdomains of the increased quality i.e. effective clusters will be defined further.

\section{Effective implementation of blast-furnace processes finding}

in admissible domain as an example

We will consider an example of the offered approach application to the blast-furnace process control. This approach to the blast-furnace process efficiency increasing features the using of actual operation data in addition to the existing techniques of process parameters technological calculation.

We will illustrate productivity of the approach by the example. Assume that the control factors of blast-furnace process are chosen on the basis of theoretical flame temperature calculation. Formula of theoretical flame temperature calculation:

$$
T_{t f}=2405+0,75\left(T_{b}-1200\right)-5,4 W+43\left(O_{x}-21\right)-52 Q_{n g},
$$

where $T_{b}$ - blast temperature, ${ }^{\circ} \mathrm{C} ; W$ - blast moisture, $\mathrm{g} \cdot \mathrm{m}^{-3} ; O_{x}$ - oxygen content in blasting, \%; $Q_{n g}$ - natural gas volume flow, \%. Blast moisture, $W-$ is determined by the formula: $W=\varphi_{0}+\frac{1000 G}{Q_{b}}$, where $\varphi_{0}$ - natural seasonal blast moisture, $\mathrm{g} \cdot \mathrm{m}^{-3} ; G$ - the mass flow rate of steam for blast moistening, $\mathrm{kg} \cdot \mathrm{min}^{-1} ; Q_{b}$ - blast volume flow, $\mathrm{m}^{3} \cdot \mathrm{min}^{-1}$.

\section{The procedure of blast-furnace process step-by-step adjustment for the effective modes}

For the blast-furnace process to work in the effective modes area, the following procedure of control factors $\mathbf{x}$ adjustment is offered in this paper. 
To start adjustment it is necessary to have at least three implementation of the blast-furnace process control factors represented by vector values of the control factors $\mathbf{x}_{1}, \mathbf{x}_{2}, \mathbf{x}_{3}$.

In vector space these values can be connected by straight lines which analytical forms correspond to the following ratios:

$$
\begin{aligned}
& (1-\alpha) \mathbf{x}_{1}+\alpha \mathbf{x}_{2}, \\
& (1-\beta) \mathbf{x}_{2}+\beta \mathbf{x}_{3}, \\
& (1-\gamma) \mathbf{x}_{1}+\gamma \mathbf{x}_{3,}, \\
& \alpha, \beta, \gamma \in[0,1] .
\end{aligned}
$$

Then the performance criterion of process implementation on the basis of linear convolution of two indicators of productivity and coke loading size is defined. For this purpose these indicators are normalized

$$
p=\frac{P}{P_{a v}}, k=\frac{C}{C_{a v}},
$$

where $p$-relative cast iron production; $k$ - relative coke rate; $P_{a v}$ - average productivity; $C_{a v}$ - average coke rate; $P$ - current productivity; $C$ - current coke rate.

Performance criterion:

$$
E=\lambda_{1} p+\lambda_{2} k^{-1}, \quad \lambda_{1}, \lambda_{2} \geq 0, \quad \lambda_{1}+\lambda_{2}=1 .
$$

where $\lambda_{1}, \lambda_{2}$ - the weight of indicators $n$ and $\kappa$ respectively as a part of criterion (3), reflecting importance of taking into account productivity and coke saving as a part of the general performance criterion.

For vectors $\mathbf{x}_{1}, \mathbf{x}_{2}, \mathbf{x}_{3}$ on the basis of the performance criterion (3) we will get $E_{1}, E_{2}, E_{3}$ characteristics respectively.

Assume that value of $E_{1}$ is less than values of $E_{2}, E_{3}$. In this case vector $\mathbf{x}_{1}$ is considered to be inefficient and is out of consideration.

For vectors $\mathbf{x}_{2}, \mathbf{x}_{3}$ we will calculate a mean vector which is between these two vectors $\mathbf{x}_{a v}=0,5 \mathbf{x}_{2}+0,5 \mathbf{x}_{3}$.

The assessment of $\mathbf{x}_{4}$ perspective value of a parameters vector $\mathbf{x}$ is done by $\mathbf{x}_{4}=-\mathbf{x}_{1}+2 \mathbf{x}_{a v}$.

In Fig. 4 the illustration of perspective $\mathbf{x}_{4}$ value assessment is given.

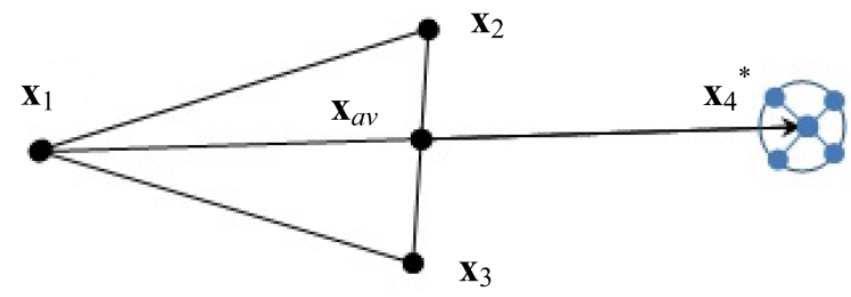

Fig. 4

The perspective vector is implemented as the recommended value of the control factors $\mathbf{x}$ vector. In order that process of search is carried out in n-dimensional space, the search of a perspective vector is performed on the basis of orthogonal planning of decision-making. Due to this implementation we see true values of $P_{4}, C_{4}$ characteristics.

The procedure of the next perspective $\mathbf{x}_{5}$ value calculation can be applied iteratively to the set of three vectors $\mathbf{x}_{2}, \mathbf{x}_{3}, \mathbf{x}_{4}$ and calculation process will be continued in cycles.

Calculation proceeds until there is a growth of a process performance factor. The performance factor goes in cycles at some stage of the process. In this case in a random way in the space of parameters around the solution found vectors of the control parameters $\mathbf{x}$ values are generated until two vectors with the best values of performance factor are received and adjustment process is repeated iteratively. The illustration of this process based on actual data is given in Fig. 5.

This technique is implemented in the form of the appropriate program in ACS PolyTER and focused on using in such automated systems as "master adviser". 


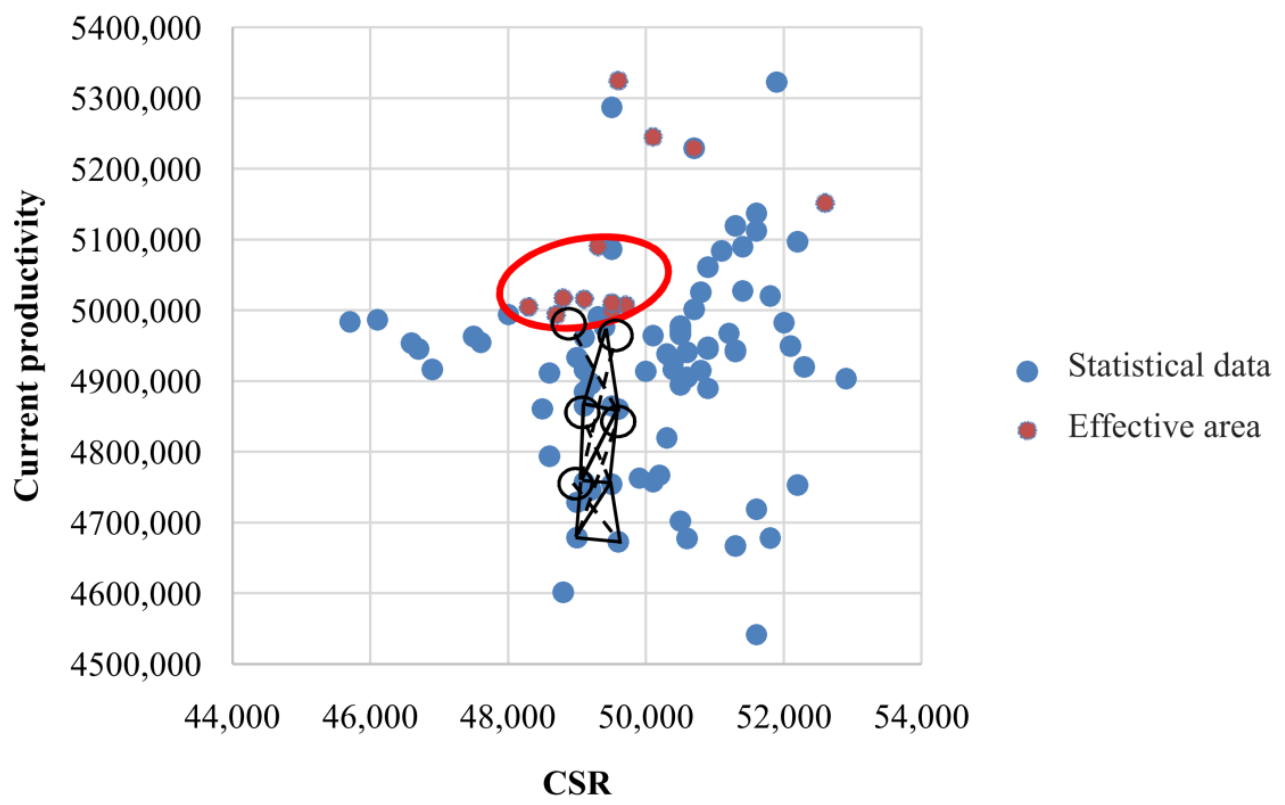

Fig. 5. Step-by-step blast-furnace process parameters adjustment

Table 1

\begin{tabular}{|l|c|c|c|}
\hline \multicolumn{1}{|c|}{ Date } & $\begin{array}{c}\text { Production of cast iron } \\
\text { in nominal per day }\end{array}$ & $\begin{array}{c}\text { Skip coke consumption } \\
\text { (fr. }+40)\end{array}$ & $\begin{array}{c}\text { Performance criterion } \\
E\end{array}$ \\
\hline $\begin{array}{l}\text { Starting point of } \\
\text { search } \\
30.06 .2015\end{array}$ & 4742,960 & 497,683 & 0,9502 \\
\hline $\begin{array}{l}\text { Effective point } \\
23.02 .2015\end{array}$ & 5270,020 & 437,869 & 1,067 \\
\hline
\end{tabular}

Table 2

\begin{tabular}{|c|c|c|c|}
\hline Date & $\begin{array}{c}\text { Production of cast iron } \\
\text { in nominal per day }\end{array}$ & $\begin{array}{c}\text { Skip coke consumption } \\
(\text { fr. }+40)\end{array}$ & $\begin{array}{c}\text { Performance criterion } \\
E\end{array}$ \\
\hline Indicators changing, \% & 11,112 & $-12,019$ & 12,286 \\
\hline
\end{tabular}

The step-by-step adjustment of the blast furnace process to an effective mode resulted in the $12 \%$ increase of calculated performance criterion, while the rate of cast iron production increased $11 \%$, along with the $12 \%$ coke consumption reduction (Tables 1,2 ).

\section{Decision making on the basis of an effective cluster}

Process of the efficiency index improvement eventually comes to the parameters local domain where the algorithm goes in cycles and by that we obtain the effective cluster domain with the increased quality of process.

The main point of the procedure under consideration is the effective modes domains determination. The effective modes domain is distinguished in space of operating parameters by the quality indicators set. As industrial process control has a dynamic nature, the domain distinguished has to be stable. It means that time has to be one of the operating parameters space coordinates, and the space should be a generalized function space. Elements of this space are the operating parameters implementation during the time. Thus tracing time-base deflection of parameters' evolution is used to estimate their stable belonging to the effective modes domain during the time. It is the implementation of operating parameters stable in efficiency that is included in the domain of the functional space effective modes.

According to the methodology of model predictive control the domain of the functional space effective modes represents the model of the industrial process modes evolution. 


\section{Автоматизированные системы управления}

Besides, the choice of the effective solution is made for the first step of effective domain evolution as, according to the mentioned above, the subsequent steps will obviously belong to the effective solutions domain.

The effective solution choice is made for each cluster of the increased quality. We will choose the decision with the minimum probability of the inefficient decision making out of the obtained solution set. Generally from the point of view of control process dynamics such approach leads to the making of control decisions with variable structure.

In Fig. 6 the representation of effective values domain of the blast furnace No. 10 of JSC MMK operating parameters is presented as an example. To distinguish the effective solution domain we used such criteria as performance and stability index of the blast-furnace process.

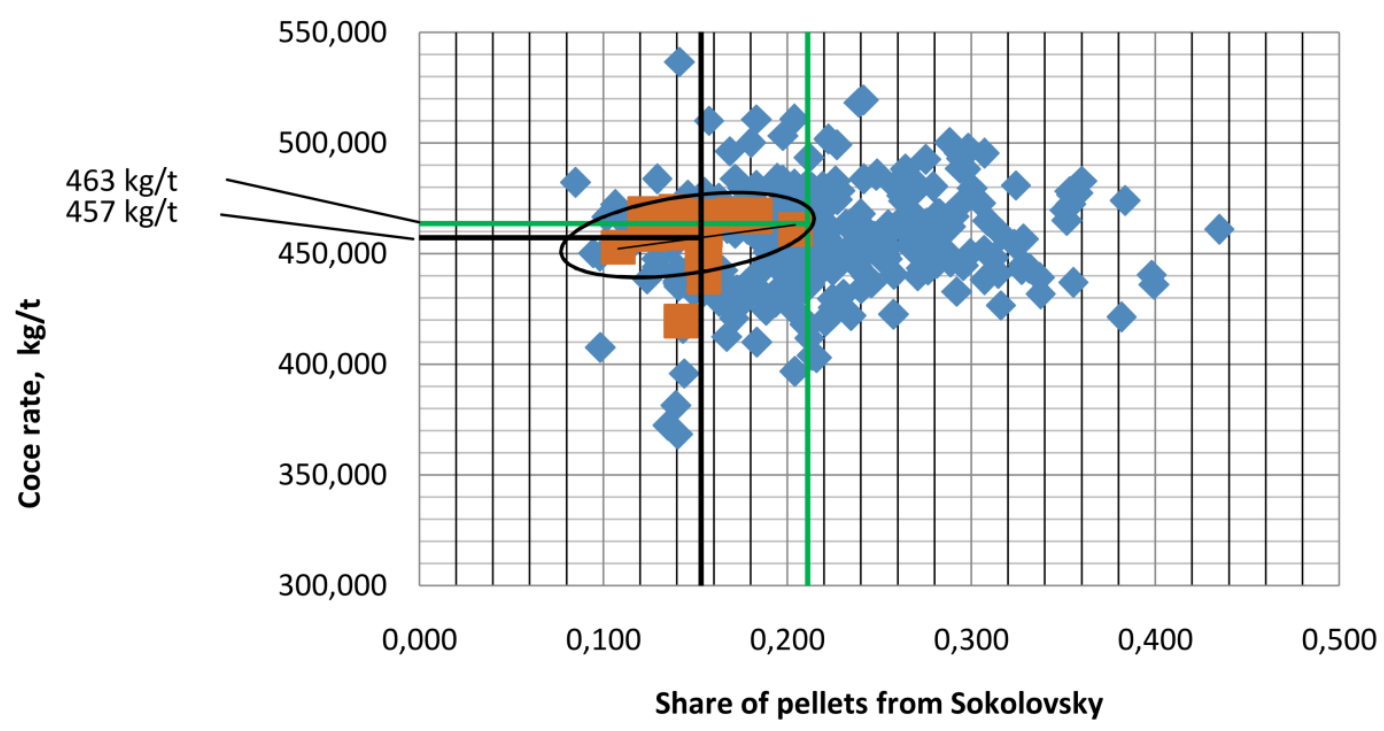

Fig. 6. Sample description of the effective values domain of the blast furnace operating parameters

The considered method allows determining the steady-state modes of industrial processes, effective in terms of productivity and resources consumption.

\section{Conclusion}

Introduction of multilayered approach to the model predictive control is an essential problem of the industrial process automation determined first of all by the high efficiency needs now. The existing level of industrial processes automation is focused on indicators values obtaining which range is in the admissible limits determined by process regulations. The next step forward is in providing the increased indicators of efficiency and quality values within the existing process regulations. It can be achieved by using the integrated approach to the blast-furnace process control on the basis of more accurate models application reflecting its dynamics from different sides; the current binding of the model parameters in real time mode to the exact process controlled; uses of modern methods of datamining for the effective control decisions making.

The process of optimization is based on the using of multidimensional simplex method and orthogonal planning of decision making in combination with method of paraelliptic approximation of effective domain.

This technique is implemented in the form of the appropriate program and intended for using in the "master adviser" automated systems.

\section{References}

1. Kazarinov L.S., Barbasova T.A. Case Study of the Conservation Power Plant Concept to Energy Conservation in a Metallurgical Works. Procedia Engineering, 2015, vol. 129, pp. 578-586. DOI: 10.1016/j.proeng.2015.12.060 
2. Kazarinov L.S., Barbasova T.A., Kolesnikova O.V, Shnayder D.A. Complex Hydraulic Network Dispatching Control Based on Signal-Oriented Macromodel. 1st Conference on Modelling, Identification and Control of Nonlinear Systems (MICNON-2015), Saint Petersburg, Russia, June, 24-26, 2015, vol. 48, iss. 11, pp. 92-96. DOI: 10.1016/j.ifacol.2015.09.165.

3. Kazarinov L.S., Barbasova T.A, Kolesnikova O.V., Zakharova A.A. Method of Multilevel Rationing and Optimal Forecasting of Volumes of Electric Energy Consumption by an Industrial Enterprise. Automatic Control and Computer Sciences, 2014, vol. 48, no. 6, pp. 324-333. DOI: 10.3103/S0146411614060054.

4. Lee E.B., Markus. L. Foundations of Optimal Control Theory. New York: Wiley, 1967. 576 p.

5. Tsypkin Ya.Z. Adaptatsiaya i obuchenie $v$ avtomaticheskikh sistemakh (Adaptation and Training in Automatic Systems). Moscow, Science Publ., 1968. 400 р. [Цыпкин Я.3. Адаптация и обучение в автоматических системах. М.: Наука, 1968. 400 с.]

6. Richalet J.B., Rault A., Testud J.L., Papon J. Model Predictive Heuristic Control: Applications to Industrial Processes. Automatica, 1978, 14, pp. 413-428.

7. Clarke D.W. et al. Generalized Predictive Control. Part I \& II. Automatica, 1987, vol. 23, no. 2, pp. $137-160$.

8. Clarke D.W. et al. Properties of Generalized Predictive Control. Automatica, 1989, vol. 25, no. 6, pp. $859-875$.

9. De Keyser R.M.C., Van de Velde Ph.G.A., Dumortier F.A.G. A Comparative Study of Selfadaptive Long-range Predictive Control Methods. Automatica, 1988, vol. 24, no. 2, pp. 149-163.

10. Garcia C.E., Prett D.M., Morari M. Model Predictive Control: Theory and Practice - a Survey. Automatica, 1989, 25(3), pp. 335-348.

11. Ricker N.L. Model Predictive Control: State of the Art. In Y. Arkun, W.H. Ray (Eds.), Chemical Process Control - CPC IV, Fourth International Conference on Chemical Process Control. Amsterdam: Elsevier, 1991, pp. 271-296.

12. Morari M., Lee J.H. Model Predictive Control: The Good, the Bad, theUgly. Chemical Process Control - CPC IV, Fourth International Conference on Chemical Process Control. Amsterdam, Elsevier, 1991, pp. 419-444.

13. Muske K. R., Rawlings J.B. Model Predictive Control with Linear Models. A.I.CH.E. Journal, 1993, 39(2), pp. 262-287.

14. Mayn D.Q. Nonlinear Model Predictive Control: An Assessment. Fifth International Conference on Chemical Process Control AICHE and CACHE, 1997, pp. 217-231.

15. Lee, J. H., \& Cooley, B. Recent Advances in Model Predictive Control and Other Related Areas. Fifth International Conference on Chemical Process Control AICHE and CACHE, 1997, pp. 201-216.

16. José Manuel Mesa Fernández, Valeriano Álvarez Cabal, Vicente Rodríguez Montequin, Joaquín Villanueva Balsera. Online Estimation of Electric Arc Furnace Tap Temperature by Using Fuzzy Neural Networks. Engineering Applications of Artificial Intelligence, 2008, 21, pp. 1001-1012.

Received 21 December 2015 


\title{
МНОГОСЛОЙНЫЙ ПОДХОД К МОДЕЛЬНО-УПРЕЖДАЮЩЕМУ УПРАВЛЕНИЮ ТЕХНОЛОГИЧЕСКИМ ПРОЦЕССОМ
}

\author{
Л.С. Казаринов, Д.А. Шнайдер, Т.А. Барбасова \\ Южно-Уральский государственный университет, г. Челябинск
}

\begin{abstract}
Предложен метод повышения эффективности технологических процессов, основанный на многослойном подходе к решению задачи управления. В соответствии с предложенным подходом существующий технологический регламент ведения процесса оценивается с точки зрения реальной точности удержания режимных параметров и используется как нормативное ограничение, определяющее область их допустимых значений. В рамках указанной области реализуется процесс оптимизации значений управляемых режимных параметров по текущим данным эксплуатации. Процесс оптимизации основан на использовании многомерного симплекс-метода и ортогонального планирования поиска решения в сочетании с методом эллиптической аппроксимации эффективной области. Приводится пример использования предложенного подхода для задачи повышения эффективности доменного процесса.

Ключевые слова: доменный проиесс, многослойный подход, метод эллиптической аппроксимации, модельно-упреждающее управление.
\end{abstract}

Казаринов Лев Сергеевич, д-р техн. наук, профессор, заведующий кафедрой автоматики и управления, Южно-Уральский государственный университет, г. Челябинск; kazarinovls@ susu.ru.

Шнайдер Дмитрий Александрович, д-р техн. наук, профессор кафедры автоматики и управления, Южно-Уральский государственный университет, г. Челябинск; polytech@mail.ru.

Барбасова Татьяна Александровна, канд. техн. наук, доцент кафедры автоматики и управления, Южно-Уральский государственный университет, г. Челябинск; tatyana_barbasova@mail.ru.

Поступила в редакцию 21 декабря 2015 2.

\section{ОБРАЗЕЦ ЦИТИРОВАНИЯ}

Kazarinov, L.S. Multilayered Approach to Model Predictive Industrial Process Control / L.S. Kazarinov, D.A. Shnayder, T.A. Barbasova // Вестник ЮУрГУ. Серия «Компьютерные технологии, управление, радиоэлектроника». - 2016. - Т. 16, № 1. - С. 137-144. DOI: $10.14529 /$ ctcr160112

\section{FOR CITATION}

Kazarinov L.S., Shnayder D.A., Barbasova T.A. Multilayered Approach to Model Predictive Industrial Process Control. Bulletin of the South Ural State University. Ser. Computer Technologies, Automatic Control, Radio Electronics, 2015, vol. 16, no. 1, pp. 137-144. DOI: $10.14529 / \mathrm{ctcr} 160112$ 